\title{
SEASONALITY OF FISHING IN SOUTH-EAST QUEENSLAND
}

\author{
IAN WALTERS
}

\begin{abstract}
Seasonality determinations by growth ring analysis are provided for 112 marine fish vertebrae excavated from Late Holocene archaeological sites in coastal south-east Queensland. These indicate that fishing was undertaken throughout the year. It is concluded that models of Late Holocene subsistence and settlement in this region which rely on an assumption of winter dominance in marine fish harvesting must be rejected. This has implications for models which relate seasonal resource gluts to forms of social complexity.
\end{abstract}

\section{Introduction}

Morwood (1986, 1987) sought to demonstrate social complexity in the middle to late Holocene of south-east Queensland. He argued that the development of complex patterns of exchange were accompanied by increases in population which were based upon increases in carrying capacity (Morwood 1987:348). Carrying capacity was increased in the region by virtue of the "biologically rich estuarine and mudflat-mangrove areas" which developed after the middle Holocene marine transgression (Morwood 1986:88), and the trigger for social complexity was essentially a set of "social adaptations" concerned with "strategies tor effectively increasing the carrying capacity of regional resources" Morwood (1987:337). Prior to $6000 \mathrm{BP}$ the regional economy was dependent upon nut harvests from hinterland groves of the Bunya Pine A raucaria bidwillii together with some low level marine resource exploitation (Morwood 1986:90; 1987:344). After ( $1000 \mathrm{BP}$ the region "is distinguished by the bimodal distribution of two geographically and seasonally 'patchy' resources" (Morwood 1987:344): the "triennial" crops of bunya nuts from the hinterland Bunya Mountains and Blackall Range in summer and marine fish, particularly the "runs of sea mullet in Moreton Bay" (Morwood 1987:339) in winter.

According to Morwood's model, this new bimodal distribution of "resource gluts" promoted social strategies such as "demographic flexibility" (Morwood 1986:88, 1987:348). Population movement between the inland and the coast began in order to exploit the two seasonally patchy resources. The viability of the model depends on the seasonal patchiness of the resources, and it can essentially be tested by examination of this. In this paper I ask the question: did marine fish harvesting peak narrowly in winter (June - August) in south-east Queensland during the late Holocene? To answer, I present an analysis of seasonality in a sample of archaeologically recovered fish remains from southeast Queensland.

\section{The Study Area and its Prehistory}

Southeast Queensland as a region is considered to be bounded in the west by the Great Dividing Range, in the east by the Pacific ocean, in the south by the Border Ranges and Tweed River which separate it from northern New South Wales, and in the north by the Burnett River basin. The region is divisible into the sub-coastal highlands, the sub-coastal lowlands and the coastal lowlands (Hall 1982; Hall and Hiscock 1988; Lilley 1984).

Moreton Bay, occupying an area of some 1,600 sq. $\mathrm{km}$ on the southeast Queensland shelf, is a triangular embayment enclosed on the west by the mainland and on the east by large sand islands (Figure 1) (Hekel et al. 1979:7). The water body approximately $80 \mathrm{~km}$ long, and $35 \mathrm{~km}$ wide in the north, tapers to less than $5 \mathrm{~km}$ wide in the south; in places it is more than $40 \mathrm{~m}$ deep. It is divisible into a deep northern sector and a narrower southern region in which numerous small sand islands occur. Although the Moreton Bay area is an ancient feature in the landscape of continental Australia, showing evidence of structural and sedimentary formation at least half a million years ago, the essential form of the contemporary bay took shape during the period of marine transgression which terminated in middle Holocene times around 6,000 years ago. It is now divided into a number of sub-units such as Deception Bay and Bramble Bay. Streams such as the Pine River, Caboolture River, as well as the Brisbane River itself, feed into the bay from the west.

Human occupation of coastal southeast Queensland dates to the late Pleistocene. Morwood (1987:343) noted the Talgai site, and Neal and Stock (1986) provided evidence from the Wallen Wallen Creek site for a continuous sequence from about 20,000 years ago until the European period. Their data, and those presented in Hall (1986), Hall and Lilley (1987), Hall et al. (1987), Hall and Hiscock (1988), Morwood (1986, 1987) Nolan (1986), Walters $(1987,1989)$, and Walters et al. (1987) showed, for coastal southeast Queensland, what has been called a "dramatic increase in occupation intensity during the late Holocene" (Neal \& Stock 1986:618). It has been argued that this relates to the development of the marine fishery (Morwood 1987; Walters 1987, 1989).

\section{The Fishing Calendar in the European Period}

Studies such as Morwood's $(1986,1987)$ and the present one depend upon a uniformitarian assumption: that relevant ecological and physiological phenomena and behaviour patterns observed in contemporary fish populations operated in the same ways in the prehistoric period under discussion (Late Holocene). In the European period the commercial net fishery in southeast Queensland has concentrated heavily on mullet, 


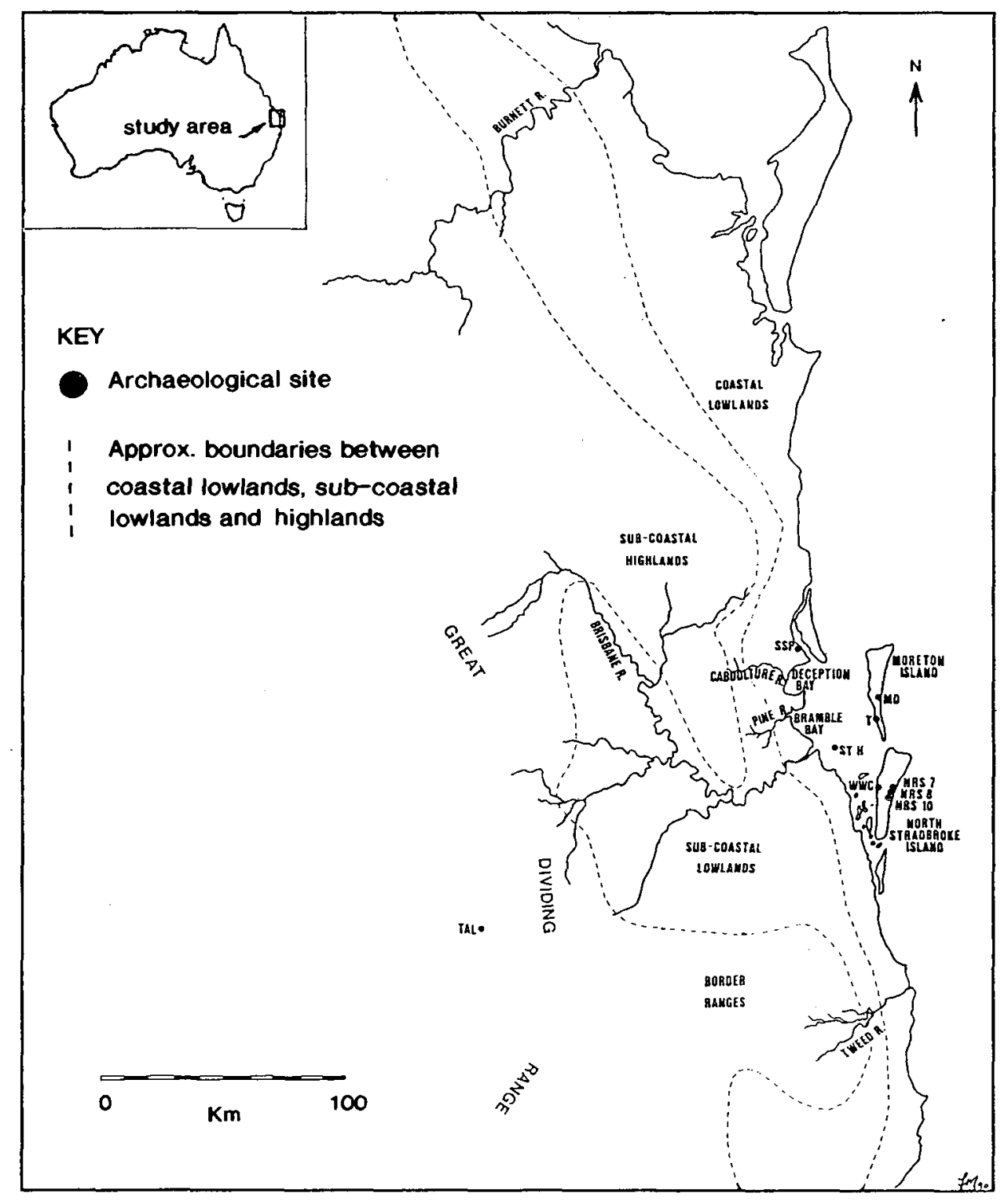

Figure 1: The study area

principally the Sea Mullet Mugil cephalus, which run along the eastern beaches and over the shallow water mud and sand flats of the estuaries. Anglers, who also exploit beach and shallow water inshore habitats, show high priority for, and returns of, several species of whiting Sillago spp. (Pollock 1980). This is convenient for two reasons. Firstly, these taxa are well represented in archaeological samples recovered from Late Holocene levels in coastal south-east Queensland. Together they constitute $36.3 \%$ of identified fish specimens. Secondly, both of these taxa, unlike all others recovered in large numbers from the archaeological sites, are theoretically amenable to seasonality determinations.

Mullet and whiting lay down annual growth rings on bones, scales and otoliths. Consequently, estimates for season of death are possible by analysis of the growth increments after the last "break" or growth ring on these anatomical elements.

Mullet growth rates change throughout the year (Kesteven 1942; Thomson 1966; Grant and Spain 1975). In sub-tropical latitudes like south-east Queensland, a growth ring is laid down in June-July as the adult fish spawn at sea. Growth continues slowly through the winter and spring months and increases rapidly as water temperatures increase in December-February, reaching its peak in March (though the data show that this ideal pattern is blurred somewhat, and that maximum growth continues through the period March-May) (Kesteven 1942; Thomson 1953). Mullet fisheries in eastern Australia during the European period have consistently shown peak catches during or before May, in some years maintaining a broad peak over the period January-May (Kesteven 1942:67, 80-82, 120-121; Thomson 1953:5557; Pollock 1977:233). However, it must be emphasised that even in off-peak periods, the commercial catches involve large tonnages, and are high relative to catches of other fish species. Off-peak catches would certainly be capable of sustaining populations of fisher-gathererhunters whose numbers were of the order of those recorded for coastal south-east Queensland at the time of European invasion (e.g. see Hall 1982; Nolan 1986).

Whiting show seasonal patterns of movement around 


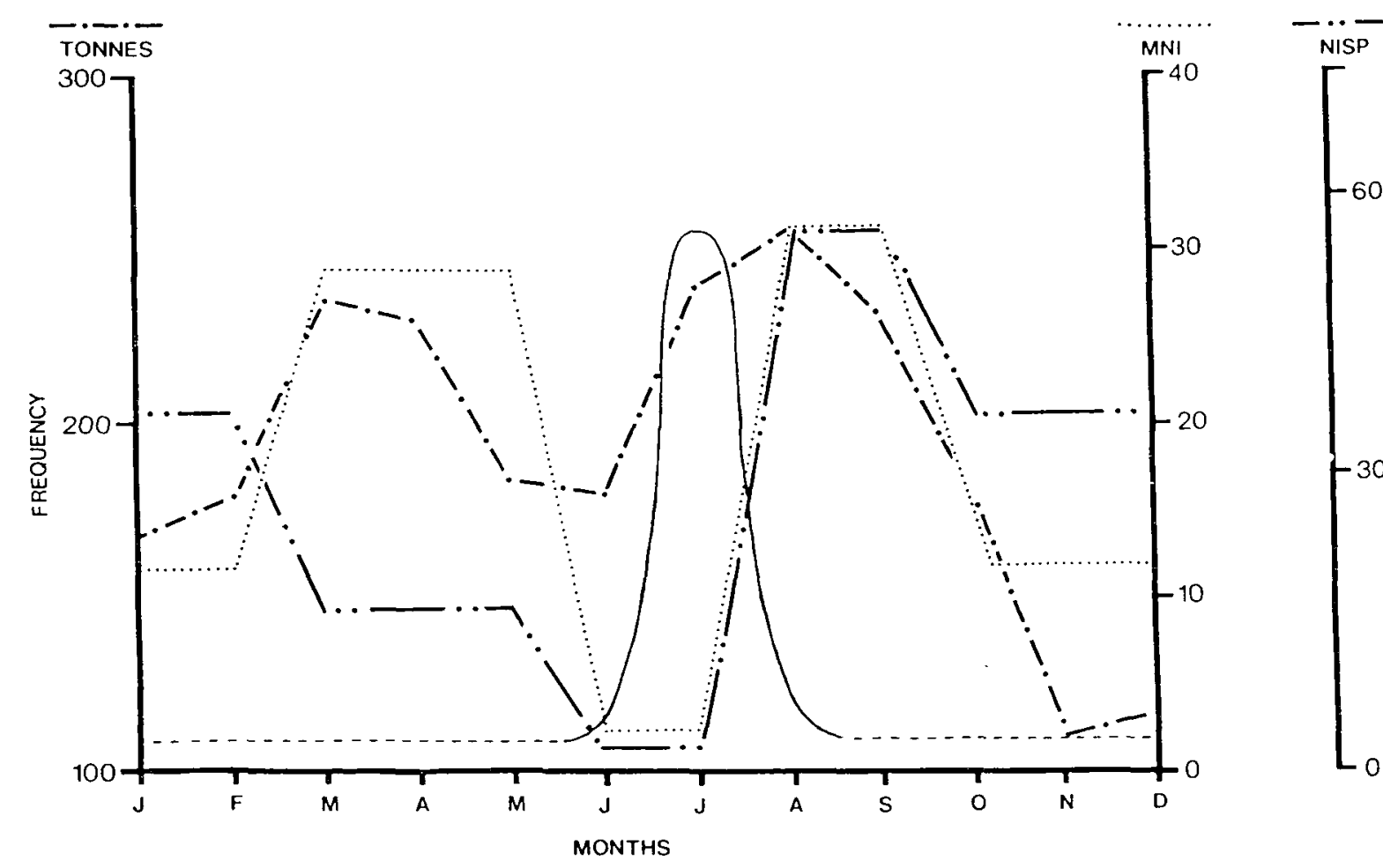

Figure 2: Modem fish tonnages, MNI and NISP from the archaeological samples, and Morwood's original curve for fishing seasonality.

south-east Queensland bays and estuaries. Maclean (1969:15) showed that Trumpeter Whiting S.maculata occur in the eastern Moreton Bay only in "summer" (presumably December-February), and that they move to the western bay in "winter" (presumably June-August). Sand Whiting S.ciliata show movements according to age classes. Dredge (1976:59) noted that adults of this species taken in "winter" months were virtually all twoyear old fish, whereas adults taken in "summer" ranged between two and nine year-old individuals. Pollock and Williams (1983:85) were quite explicit about months of harvest: catches of the so-called "summer Whiting" S.ciliata and S.analis in south-east Queensland were in fact strongly seasonal in the period August-February.

Morwood's (1986:90; 1987:344) original curve for seasonally patchy winter dominated fish harvesting is reproduced identically in Figure 2. Data from Kesteven (1942), Thomson (1953), Pollock (1977) and Pollock and Williams (1983) are collated to produce the contemporary fish harvesting pattern in south-east Queensland. These data show that in the European period there is no justification for an assumption of a single peak in total fish catches which is confined to June-August. Figure 2 shows the pattern for monthly returns of commercially caught fish in southeast Queensland drawn to the same scale as Morwood's (1986:90, 1987:344) impression of the late Holocene pattern. Morwood's original graph showed no actual months. As the peak of his curve was meant to encompass winter, I have taken its maximum value to denote July and have divided the abscissa into equal monthly units. The catch curve from the fisheries biology literature is bimodal, with peak tonnages being taken in (1) March-April and (2) July-September. I have standardised it so that the largest catch (August) is the same height as the peak on Morwood's graph. Morwood's curve has low values for all non-winter months whereas the fisheries data indicate such low values only in November-December. However, in terms of the quantities of fish required by populations of fishergatherer-hunters, Figure 2 shows that relatively large amounts of fish were available all year round.

Morwood's (1987:348) characterisation of marine fish availability in the Late Holocene of southeast Queensland as "coastal winter fish runs" misrepresents the complex ecological reality. Where Morwood's (1986:90, 1987:344) catch frequency curves derive from is unstated. They certainly do not derive from the fisheries literature. Catch records of relevant inshore shallow water fish extending from the 1890 s and turn of the century (Kesteven 1942; Thomson 1953) through modern times (Pollock 1977, 1980) can in no way be interpreted as Morwood suggests for the Late Holocene (Figure 2).

\section{Archaeological Sites and Sampling}

The present study examined archaeological evidence of prehistoric fishing in Moreton Bay from eight shell middens spread across a spectrum of environmental variability. The sites sampled various fishing habitats (Figure 1): the mainland foreshores (e.g. site SSP), small islands in the bay (e.g. $\mathrm{StH}$ ), and from the bayside (e.g. 
T and WWC) and surfside of the dune-island barriers Moreton Island and North Stradbroke Island (e.g. MD, NRS 7, NRS 8, NRS 10). SSP is a large midden complex on the foreshore of Deception Bay. The site dates to $2290+/-100$ b.p. (Beta-15810/B), with the fish remains concentrated in layers, approximately $1 \mathrm{~m}$ thick, from the last 1,000 years. StH is a small midden some $50 \mathrm{~cm}$ deep on St Helena Island, from which Alfredson (1983) obtained a date, corrected for marine reservoir effect, of $1730+/-210$ BP (Beta 6141). Toulkerrie midden $(T)$ is an extensive midden situated on a vegetated sand dune. A date of $370+/-75$ b.p. (T11096) (Hall 1984) was obtained from a shell matrix rich in fish remains. Minner Dint (MD) is a shell midden layer in surf-beach dune on the east coast of Moreton Island dated to $520+/-75$ b.p. (Hall 1980). The four North Stradbroke Island sites include the Wallen Wallen Creek site (WWC) which has been found to have Pleistocene antiquity (Neal \& Stock 1986). This sequence shows serious maritime exploitation only in its most recent levels, and was for its early history a riverside site some $30 \mathrm{~km}$ form the sea. Ages for the other three shell middens (the NRS sites) are $470+/-60$, $450+/-60,410+/-50$ (Richardson 1984), and these convert to modern when corrected for a 450 year marine reservoir effect.

All sites were sampled by controlled excavation, and the material, after being sieved, washed and bagged, was sorted and the fish remains analysed in the laboratory (Walters 1987). The evidence indicates that fishing, on a scale detectable in the archaeological record, began around $2000 \mathrm{BP}$, some 4,000 years after the formation of the modern bay.

\section{Analysis of Archaeological Samples}

I examined vertebrae from fish species which were known to show regular growth patterns related to consistent annual "checks" or "breaks" in growth, the so-called growth rings. Mullet and Whiting vertebrae from various sites and levels were examined under a microscope to determine whether growth rings could be read. Most of the bones were too eroded at their margins or on the faces of their centra to be reliable. A total of 112 bones proved amenable to analysis, and these constitute the sample discussed here.

Local representatives of the whiting genus Sillago are difficult to speciate using bones and otoliths. However, the Trumpeter Whiting S.maculata is somewhat smaller than the two so-called "Summer" Whiting species S.ciliata and S.analis. Whiting remains were recovered from Toulkerrie (T), Minner Dint (MD), and the NRS sites, and these bones and otoliths imply relatively large fish. These remains could only be assigned to Trumpeter Whiting if they were an unusually large-bodied population. Were this so however, their presence in the eastern bay would indicate that fishing practices were taking place in the November-March season.

It is more likely, given the size of the remains, that whiting caught at these sites were S.ciliata or S.analis, the so-called "summer whiting". Were these fished in "winter", the catches should be confined to 2 year-old individuals (Dredge 1976:59). The whiting sample $(n=36)$ shows a frequency distribution of age classes ranging up to $6+$ year-old fish (Table 1 ), which complies with Dredge's (1976:59) criterion for a "summer" season of death. As noted above, this "summer" peak for whiting is more correctiy defined as the August-February period (Pollock and Williams 1983:85).

Table 1: The number of whiting vertebrae assigned to each age class by growth ring analysis $(n=36)$

\begin{tabular}{|l|c|c|c|c|c|c|}
\hline Age Class & $1+$ & $2+$ & $3+$ & $4+$ & $5+$ & $6+$ \\
Number of Specimens & 2 & 8 & 11 & 9 & 5 & 1 \\
\hline
\end{tabular}

Table 2: Season of death for archaeological mullet vertebrae $(n=76)$

\begin{tabular}{|c|c|c|}
\hline \% Growth after check & Time of Death & No. of Specimens \\
\hline $1-20$. & June - July & 2 \\
$21-50$ & August - September \\
$51-75$ & October - February & 38 \\
$75-100$ & March - May & 19 \\
\hline
\end{tabular}


Mullet vertebrae $(n=76)$ also proved amenable to age and growth analysis. Table 2 shows that the archaeological sample of mullet were caught throughout the year. There are only two specimens from the JuneJuly period, but all other times of the year are relatively well represented. Fish were not only caught at the time when modern commercial catches are at their peak (January-May), but were taken in all months, especially the period August-May.

\section{Discussion and Conclusions}

Age and growth analysis of Late Holocene archaeological fish vertebrae suggests that whiting were caught at least in the period August-February, while mullet were harvested in all months of the year, especially AugustMay. Given the uniformitarian assumption noted above, the data presented here reject Morwood's $(1986,1987)$ notion that significant exploitation of fish in the late Holocene of south-east Queensland was confined to the June-August season.

As Morwood's (1986, 1987) model for the development of complexity in south-east Queensland relies upon the notion of seasonally restricted resources, especially harvesting of fish runs in June-August, it can be rejected by the seasonality data. The evidence presented here and elsewhere (Hall 1982, 1986; Hall et al. 1987; Nolan 1986; Walters 1987, 1988, 1989) does not conflict with ideas of social and cultural complexity in the region during the prehistoric period under discussion. What it does suggest is that characterisations of complexity gain nothing from models which resort to simplistic determinism.

The data presented here also refute other models related to the idea of a nomad population which tracked "resource gluts" (Morwood 1986:88). According to such models (e.g. Draper 1978, 1980; White and O'Connell 1982) people camped on the coast for a particular time of the year to exploit marine resources, and departed for the inland when these "gluts" abated. Draper (1978, 1980) concluded that in south-east Queensland, summer should be the time of dispersal, when people moved away from the coast. White and O'Connell (1982:135) followed Draper in modelling subsistence-settlement in the region: they stated that coastal south-east Queensland would not have been occupied during "Late Summer". According to the archaeological evidence I have presented here, these models appear to be wrong.

\section{Acknowledgments}

Peter Hiscock read an earlier draft and discussed various aspects of the paper with me. Fiona Mowat drew the figures.

\section{References Cited}

Alfredson, G. 1983 St Helena Island - a changing pattern of exploitation? A ustralian A rchaeology 17, 79-86.

Draper, N. 1978 A Model of Aboriginal Subsistence and Settlement in the Moreton Bay Region of
Southeast Queensland. Unpublished BA(Hons) Thesis, University of Queensland.

Draper, N. 1980 Food resources of the Moreton Bay Aborigines. University c)f Queensland A nthropology Museum, Occasional Papers in Anthropology 10, 124-147.

Dredge, M.C.L. 1976 Aspects of the Ecology of Three Estuarine Dwelling Fish in South East Queensland. Unpublished MSc Thesis, University of Queensland.

Grant, C.J. and A.V. Spain. 1975 Reproduction, growth and size allometry of Mugil cephalus Linnaeus (Pisces: Mugilidae) from North Queensland inshore waters. A ustralian Journal of Zoology 23, 181-201.

Hall, H.J. 1980 Minner Dint: a recent Aboriginal midden on Moreton Island. University of Queensland Anthropology Museum, Occasional Papers in Anthropology 10, 94-112.

Hall, H.J. 1982 Sitting on the crop of the bay: an historical and archaeological sketch of Aboriginal settlement and subsistence in Moreton Bay. In S. Bowdler (ed.), Coastal Archaeology in Eastem A ustralia, pp.79-85. Australian National University, Canberra.

Hall, H.J. 1984 Exploratory excavation at Toulkerrie midden (LB:B175), Moreton Tsland, S.E. Queensland. Queensland A rchaeological Research 1, 61-84.

Hall, J. 1986 Exploratory excavation at Bushrangers Cave (Site LA:All), a 6000-year-old campsite in southeast Queensland: preliminary results. A ustralian A rchaeology 22:88-103.

Hall, J. and P. Hiscock. 1988 The Moreton region archaeological project (MRAP) Stage 11: an outline of objectives and methods. Queensland A rchaeological Research 5:4-24.

Hall, J. and I. Lilley. 1987 Excavation at the New Brisbane Airport Site (LB:C69): evidence for early mid-Holocene occupation in Moreton Bay, SE Queensland. Queensland Archaeological Research 4:54-79.

Hall, J., A. Nolan and I. Walters. 1987 The Sandstone Point Archaeological Project: Stage 1. Report to the Archaeology Branch, Queensland Department of Community Services, Brisbane.

Hekel, H., W.T. Ward, M. Jones and D.E. Searle. 1979 Geological development of northern Moreton Bay. In A. Bailey and N.C. Stevens (eds), Northem Moreton Bay Symposium, pp.7-18. Royal Society of Queensland, Brisbane.

Kesteven, G.L. 1942 Studies in the biology of Australian mullet. I. Account of the fishery and preliminary statement of the biology of $M$ ugil dobula Gunther. Council for Scientific and Industrial Research, Bulletin, 157.

Lilley, I. 1984 Late Holocene subsistence and settlement in subcoastal Southeast Queensland. Queensland Archaeological Research 1, 8-32.

Maclean, J.L. 1969 A Study of the Biology of Winter Whiting Sillago maculata (Quoy \& Gaimard) in Moreton Bay. Unpublished MSc Thesis, University 
of Queensland.

Morwood, M.J. 1986 The archaeology of art: excavations at Maidenwell and Gatton Shelters, S.E. Queensland. Queensland A rchaeological Research 3, 88-132.

Morwood, M.J. 1987 The archaeology of social complexity in South-east Queensland. Proceeding of the Prehistoric Society 53, 337-350.

Neal, R. and E. Stock. 1986 Pleistocene occupation in the south-east Queensland coastal region. Nature $323,618-621$.

Nolan, A. 1986 Sandstone Point: Temporal and Spatial Patterns of Aboriginal Site Use at a Midden Complex, South-east Queensland. Unpublished BA(Hons) Thesis, University of Queensland.

Pollock, B.R. 1977 Fisheries in the waters adjacent to Fraser Island. University of Queensland Anthropology Museum, Occasional Papers in Anthropology 8, 231-236.

Pollock, B.R. 1980 Surprises in Queensland angling study. A ustralian Fisheries 39(4), 17-19.

Pollock, B.R and M.J. Williams. 1983 An assessment of the angling fishery for Summer Whiting, Sillago ciliate and S.analis, in Moreton Bay, Queensland from 1959 to 1980. Procsedings of the Royal Society of Queensland 94, 85-90.

Richardson, N. 1984 An archaeological investigation of sandmining lease SML931 on North Stradbroke Island. In R.J. Coleman, J. Covacevich \& P. Davie (eds) Focus on Stradbroke, pp.23-32. Brisbane: Boolarong Publications.
Thomson, J.M. 1953 Status of the fishery for Sea Mullet (Mugil cephalus Linnaeus) in eastern Australia. Australian Journal of Marine and Freshwater Research 4, 41-81.

Walters, I. 1987 Another Kettle of Fish: The Prehistoric Moreton Bay Fishery. Unpublished PhD Thesis, University of Queensland.

Walters, I. 1988 Fish hooks: evidence for dual social systems in south-eastern Australia? Australian A rchaeology 27:98-114.

Walters, I. 1989 Intensified fishery production at Moreton Bay, South-east Queensland, in the Late Holocene. Antiquity 63:215-224.

Walters, I., P. Lauer, A. Nolan, G. Dillon and M. Aird. 1987 Hope Island: salvage excavation of a Kombumerri site. Queensland Archaeological Research 4:80-95.

White, J.P. and J.F. O'Connell. 1982 A Prehistory of A ustralia, New Guinea and Sahul. Academic Press, Sydney. 